\title{
Regional development through improving products and services case study: El Triunfo, BCS.
}

\author{
Desarrollo Regional a través de mejorar productos y servicios caso de estudio: El \\ Triunfo, BCS.
}

VALDEZ-GUERRERO, Raquel $\dagger^{*} \&$ ROBLES-ARIAS, Isela Margarita

Tecnológico Nacional de México/ Instituto Tecnológico de La Paz

ID $1^{\text {st }}$ Author: Raquel, Valdez-Guerrero / ORC ID: 0000-0003-0972-0189, CVU CONACYT: 407004

ID $1^{\text {st }}$ Coauthor: Isela Margarita, Robles-Arias / ORC ID: 0000-0001-5164-156X, CVU CONACYT: 404596

DOI: $10.35429 / J U R R E .2020 .7 .4 .9 .14$

Received July 01, 2020; Accepted November 10, 2020

\begin{abstract}
The objective of the project is to make a proposal for the improvement of products and services that are currently provided in Triunfo B.C.S., by the inhabitants of that place and to promote the development of the region by enhancing the quality of these, taking advantage of the fact that in this town there are opportunities to carry out activities dedicated to alternative tourism. In the first place, a diagnosis was made to obtain data about the situation of the town regarding the provision of products and services, for which two questionnaires arranged on a Likert rating scale were used and can locate the attributes in a numerical assessment, to later process the data using data concentrator tables that were graphed in Excel. To carry out the analysis, the SWOT Matrix and the Minimini Maximaxi Matrix were used, locating the strategies to carry out the proposal for improvements in products and services that are offered by the inhabitants of the town and thereby promote the development of the region.
\end{abstract}

Development of the region, Quality of products and services, Improvement proposal

\begin{abstract}
Resumen
El objetivo del proyecto es hacer propuesta de mejora de productos y servicios que actualmente se prestan en la Triunfo BCS, por parte de los habitantes de ese lugar y se propicie el desarrollo de la región al potenciar la calidad de estos aprovechando que en esta localidad existen oportunidades para llevar a cabo actividades dedicadas a turismo alternativo. En primer lugar, se realizó un diagnostico para obtener datos acerca de la situación de la localidad referente a la prestación de productos y servicios, para lo que se utilizaron dos cuestionarios dispuestos en escala de valoración Likert y tener la oportunidad de ubicar los atributos en una valoración numérica, para posteriormente procesar los fatos mediante tablas concentradora de datos mismos que se graficaron en Excel. Para efectuar el análisis se utilizó la Matriz FODA y la Matriz Minimini/Maximaxi ubicando las estrategias para realizar la propuesta de mejoras de productos y servicios que se ofertan por los habitantes de la localidad y con ello se propicie el desarrollo de la región.
\end{abstract}

Desarrollo de la region, Calidad de productos y servicios, Propuesta de mejora

Citation: VALDEZ-GUERRERO, Raquel \& ROBLES-ARIAS, Isela Margarita. Regional development through improving products and services case study: El Triunfo, BCS. Journal-Urban-Rural and Regional Economy. 2020. 4-7: 9-14

\footnotetext{
* Correspondence to Author (email: alejandro. raquelvaldezgro@ hotmail.com)

$\dagger$ Researcher contributing as first author.
} 


\section{Introduction}

El Triunfo is a place full of history and with a great tourist heritage which has not been taken advantage of by the inhabitants of the region, who may well participate and properly use these spaces for their own benefit since it is observed that the incipient development that exists it is used by people who have emigrated, including foreigners. It is observed that few inhabitants participate in the provision of services and generate products for the tourism that visits the region, the potential for their attention has not been exploited and the tourist attractions that exist there have not been exploited for the benefit of the community and their own development.

The potential development of an area depends on its own resources. It offers a perspective, in addition to territorial (and not functional), microeconomic (and not macroeconomic) and product (not sectoral). The protagonism and performance of public administrations is relevant, especially local, but also regional and central. The joint action of public managers and private agents is necessary, through collective interaction. Local development is a process guided by the action of the actors, which is why it rarely occurs spontaneously from a territory (OECD, 2004).

Although the Local Development theory does not have a monolithic structure and admits a variety of approaches, its Latin American current emphasizes endogenous processes related to the capacity of local actors to define their development policies, taking advantage of external and internal opportunities in the territory. ; From an economic point of view, the creation of a productive environment that favors this process is the fundamental objective of local development initiatives. This is why necessarily - such initiatives include related public policies, placing great emphasis on an agreement between the public and private sectors and the need for shared leadership (Boisier, 2005)

Other specialists on the subject coincide in highlighting the importance of local agents in the formulation of initiatives for local development (Madoery, 2005), for which they analyze three types of policies:
First generation policies, which are characterized by the attempt to improve the attractiveness of the town (improve infrastructure, attract investment, development of mega tourism projects, etc.); the second generation, which aim to improve entrepreneurial capacity, create innovative environments and mobilize the available exogenous and endogenous resources; and the third generation, which are aimed at generating associationism and collaboration processes for development. Encouraging the community to boost the economy and job creation in this way, encourages people to stay in the region instead of going out in search of work to other communities, as is currently the case in this locality and that Young individuals who emigrate to other places in search of new opportunities see that their own training as entrepreneurs enables their roots in the community. This project aims to involve the inhabitants in the use of spaces in the growth and generation of companies. In the first part, the problem and its possible solution are disclosed.

It describes how the collection of information was carried out through questionnaires to obtain information on the perception of the products that are offered in the town, subsequently the information has been processed with the use in both questionnaires in One is the Likert scale, a method that allows measuring attitudes and knowing the degree of agreement of the respondent to any assertion. It is useful to use it in situations in which you want the person to qualify their opinion. The response categories serve to capture the intensity of the respondent's feelings. (Llaurado, 2014). To carry out the analysis, the SWOT Matrix has been used, an analysis matrix that allows detecting improvement opportunities, an alternative to carry out diagnoses and determine intervention strategies in productive and social organizations, (Hernández, 2014), and the Matrix Mini mini / Maxi maxi, where they are determined: offensive strategies maxi-maxi FO (Strengths vs. Opportunities), reorientation strategies DO mini-maxi (Weaknesses vs. Opportunities), defensive strategies maxi-mini FA (Strengths vs. Threats) and survival strategies mini-mini DA (Weaknesses vs. Threats)

(Tesis.uson.mx/digital/tesis/docs/22230, 2011), to later determine the actions for its implementation. The plan includes indicators to measure your performance. 


\section{Development}

The research is: field, qualitative and descriptive

Data collection instruments.

The method is the Likert Scale since it is a tool that allows measuring attitudes and knowing the degree of compliance of the respondent to any statement. It is useful to use it in situations in which you want the person to qualify their opinion. The response categories serve to capture the intensity of the respondent's feelings. (Llaurado, 2014).

Two questionnaires were designed applying one of them to local business owners and the other to the inhabitants of the region, as information gathering instruments, the scale was arranged in 5 response levels.

On the scale, each question was divided into response options as follows: 1 very little, 2 little, 3 fair, 4 good, 5 very good.

The first questionnaire involves the perception of the capacity they have on the business plan, they were applied to all entrepreneurs located in El Triunfo, B.C.S. and they concentrated. See table 1

\begin{tabular}{|c|c|c|c|c|c|c|}
\hline Questions & 1 & 2 & 3 & 4 & 5 & $\mathbf{T}$ \\
\hline $\begin{array}{l}\text { 1Do you consider yourself a } \\
\text { person with an entrepreneurial } \\
\text { vision? }\end{array}$ & 1 & 3 & 3 & 4 & 4 & 15 \\
\hline 2Is it easy to communicate? & 0 & 3 & 2 & 7 & 3 & 15 \\
\hline $\begin{array}{l}\text { 3Do you consider yourself } \\
\text { creative? }\end{array}$ & 2 & 2 & 4 & 6 & 1 & 15 \\
\hline $\begin{array}{l}4 \text { Do you know how to work in a } \\
\text { team? }\end{array}$ & 0 & 2 & 3 & 3 & 7 & 15 \\
\hline $\begin{array}{l}\text { 5Do you consider yourself a } \\
\text { leader? }\end{array}$ & 1 & 3 & 3 & 3 & 5 & 15 \\
\hline $\begin{array}{l}6 \text { Are you clear about your goals } \\
\text { when you want something? }\end{array}$ & 0 & 1 & 1 & 6 & 7 & 15 \\
\hline $\begin{array}{l}\text { 7Do you analyze mistakes to learn } \\
\text { from them? }\end{array}$ & 5 & 3 & 2 & 2 & 3 & 15 \\
\hline $\begin{array}{l}8 \text { Do you listen to those who bring } \\
\text { you new ideas? }\end{array}$ & 1 & 1 & 3 & 7 & 3 & 15 \\
\hline $\begin{array}{l}9 \text { Do you like to take risks on new } \\
\text { ideas? }\end{array}$ & 4 & 2 & 3 & 4 & 2 & 15 \\
\hline $\begin{array}{l}\text { 10Is it easy for you to assign tasks } \\
\text { to others? }\end{array}$ & 2 & 2 & 4 & 3 & 4 & 15 \\
\hline $\begin{array}{l}11 \text { Are you motivated to meet the } \\
\text { objectives? }\end{array}$ & 0 & 0 & 2 & 6 & 7 & 15 \\
\hline $\begin{array}{l}\text { 12Would you sacrifice your free } \\
\text { time to achieve goals? }\end{array}$ & 2 & 2 & 4 & 4 & 3 & 15 \\
\hline $\begin{array}{l}\text { 13Do you consider yourself an } \\
\text { adaptable person to change? }\end{array}$ & 3 & 3 & 2 & 4 & 3 & 15 \\
\hline $\begin{array}{l}\text { 14Are you confident in your } \\
\text { entrepreneurial ability? }\end{array}$ & 2 & 2 & 2 & 5 & 4 & 15 \\
\hline
\end{tabular}

Table 1 Survey applied to business owners Own Source
A random survey arranged on a Likert scale was applied to the population of the inhabitants of the region to find out their perception of the quality of products and services offered to the population. A sample of the population was taken, which is a total of 400 inhabitants, (data obtained from the INEGI page) using the formula.

$$
\mathrm{N}=\frac{\mathrm{N} \times \mathrm{Z}^{2} \mathrm{a} \times \mathrm{p} \times \mathrm{q}}{\mathrm{D}^{(2)} \times(\mathrm{N}-1)+\mathrm{Z}^{(2)} \times \mathrm{p} \times \mathrm{q}}
$$

Whose result is 120 inhabitants.

The information collected in the survey was processed using a concentrator table. See Table 2

\begin{tabular}{|l|c|c|c|c|c|c|}
\hline \multicolumn{1}{|c}{ Questions for } & 15 & 15 & 25 & 35 & 30 & $\mathbf{1 2 0}$ \\
\hline $\begin{array}{l}\text { 1Rate products locality } \\
\text { sale in the lon }\end{array}$ & 10 & 15 & 40 & 30 & 25 & $\mathbf{1 2 0}$ \\
\hline $\begin{array}{l}\text { 2Consider innovation / } \\
\text { products necessary }\end{array}$ & 10 & 10 & 45 & 35 & 20 & $\mathbf{1 2 0}$ \\
\hline $\begin{array}{l}\text { 3Quality of product } \\
\text { obtained care }\end{array}$ & 0 & 0 & 30 & 40 & 50 & $\mathbf{1 2 0}$ \\
\hline $\begin{array}{l}\text { 4Price / quality ratio, } \\
\text { rate the local } \\
\text { products? }\end{array}$ & 5 & 15 & 35 & 45 & 20 & $\mathbf{1 2 0}$ \\
\hline $\begin{array}{l}\text { 5.Respectful the } \\
\text { during your purchase }\end{array}$ & 0 & 0 & 20 & 60 & 40 & $\mathbf{1 2 0}$ \\
\hline $\begin{array}{l}\text { 6 Rate the order and } \\
\text { cleanliness of the } \\
\text { businesses }\end{array}$ & 15 & 15 & 30 & 30 & 30 & $\mathbf{1 2 0}$ \\
\hline $\begin{array}{l}\text { 7Recommendation of } \\
\text { products generated in } \\
\text { the locality }\end{array}$ & 10 & 10 & 40 & 40 & 20 & $\mathbf{1 2 0}$ \\
\hline $\begin{array}{l}\text { 8 The creation of new } \\
\text { businesses in the } \\
\text { locality is timely }\end{array}$ & 0 & 0 & 30 & 30 & 60 & $\mathbf{1 2 0}$ \\
\hline $\begin{array}{l}\text { 9Consider the town } \\
\text { where you can go } \\
\text { sightseeing? }\end{array}$ & 15 & 15 & 15 & 45 & 30 & $\mathbf{1 2 0}$ \\
\hline $\begin{array}{l}\text { 10Rate the quality of } \\
\text { local businesses }\end{array}$ & 15 & & & & & \\
\hline
\end{tabular}

Table 2 Quality in products and services offered in El Triunfo

Own Source

An observation matrix 4 four businesses was applied randomly, because at that time they were open to the public during the visit that was made, to collect data about the image of the businesses and the data was concentrated in the Table. See Table 3. 


\begin{tabular}{|l|l|l|l|}
\hline \multicolumn{1}{|c|}{ Criteria } & Yes & \multicolumn{2}{c|}{ No } \\
Sustomer & 4 & & $\begin{array}{l}\text { Excellent treatment as a } \\
\text { local tourist always } \\
\text { attentive to what the time } \\
\text { within the establishment } \\
\text { could offer us, we always } \\
\text { receive a cordial } \\
\text { treatment }\end{array}$ \\
\hline Infrastructure. & 2 & 2 & $\begin{array}{l}\text { Simple place, they have } \\
\text { their logo and name in } \\
\text { view of the tourist which } \\
\text { makes it a plus. }\end{array}$ \\
\hline Cleaning. & 4 & & $\begin{array}{l}\text { Cleaning in an } \\
\text { establishment always } \\
\text { speaks well of the place, } \\
\text { recommended to visit } \\
\text { and support local } \\
\text { commerce. }\end{array}$ \\
\hline $\begin{array}{l}\text { Quality } \\
\text { Products. }\end{array}$ & 2 & 2 & $\begin{array}{l}\text { Products made by local } \\
\text { artisans, 100\% talent }\end{array}$ \\
\hline
\end{tabular}

Table 3 Observation Matrix on the image of business Own Source

The information that was concentrated from the surveys applied to business owners, the data obtained was graphed as shown in graph 1

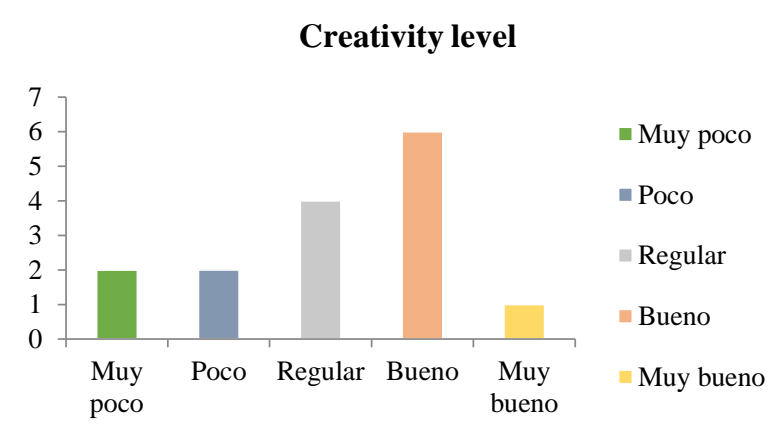

Graphic 1 Creativity level for innovation Own Source

From the graphs it can be observed in a general way that:

1. Entrepreneurial vision, 4 participants consider it as very good and 4 as good.

2. Communication level 7 participants are rated as good

3. Creativity in general is 6 participants as good

4. Teamwork, 7 of the participants get a very good score

5. Leadership 5 people get very good

6. Clarity when setting objectives 7 people mark as very good and 6 as good

7. Very few learn or want to learn from their mistakes as entrepreneurs

8. Most are willing to listen to new ideas
9. Most entrepreneurs do not want to take risks when innovating in a product

10. Most like to work in a team

11. They fight to achieve their goals

12. If they are willing to sacrifice free time to meet their goals

13. Person adaptable to change, well you consider them 4 people and 3 very good

14. Confidence in their entrepreneurial capacity, 5 good and 4 very good.

Likewise, the concentration of information on quality in products and services offered was graphed and from where it is obtained:

1. There is satisfaction with the products or services offered in the town.

2. They would like to see more products of higher quality

3. Quality is good but it can be improved.

4. The price is considered good, but it is necessary to improve the product.

5. They consider respect in customer treatment

6. Cleanliness is considered good

7. If they recommend the products and walks around the place

8. They expect new and varied businesses to exist

9. They believe that it can grow if they know how to take advantage of it and exploit it correctly.

10. Expectations meet the fundamental requirements of a locality

\section{Analysis of data}

To carry out the analysis, the SWOT Matrix was used, with the intention of detecting opportunities for improvement and obtaining:

\section{Strengths:}

Quick adaptation of the inhabitants.

Acceptance of new projects.

Government support for the community of Triunfo B.C.S.

Natural environment and architectural buildings with history.

Diversity of regional products made by the community.

Security and tranquility for visitors.

Non-crowded tourist alternatives. 


\section{Weaknesses:}

There is no academic preparation in most of the inhabitants.

Lack of tourism promotion.

Low penetration in tourism marketing channels. Little propaganda to the town and its tourist attractions.

\section{Opportunities:}

There is no resistance to change.

There are enough natural resources.

It has a lot of history in its inhabitants and architectural buildings.

Take advantage of the safety of the destination.

Manage a tourist agency with a catalog of products and destinations.

Sale of regional products.

\section{Threats:}

New businesses from people outside the community.

Little capital to run a business.

Other destinations more prepared for the perception of tourism.

This information located in the SWOT matrix, was later analyzed by placing it in the matrix, Mini-Mini Maxi-Maxi, It is an instrument which allows to create strategies from the SWOT, thanks to the fact that it compares the different variables, where the information was arranged as follows:

WT (Weaknesses / Threats), is to minimize both weaknesses and threats.

WO (Weaknesses / Opportunities), tries to minimize weaknesses and maximize opportunities.

ST (Strengths / Threats), is based on the strengths of the institution that can cope with threats from the external environment.

SO (Strengths / Opportunities), maximize both your strengths and your opportunities. See Table 3

\begin{tabular}{|c|c|}
\hline $\begin{array}{ll}\text { (Offensive } & \text { strategies) } \\
\text { Strengths vs opportunities }\end{array}$ & $\begin{array}{l}\text { (Reorientation } \\
\text { strategies) } \\
\text { Weaknesses } \\
\text { opportunities } \\
\end{array}$ \\
\hline $\begin{array}{l}\text {-Offer entrepreneurship } \\
\text { workshops to the inhabitants } \\
\text { of the region } \\
\text {-Offer to provide computer } \\
\text { and marketing workshops to } \\
\text { the people of the region to } \\
\text { make use of new technologies. }\end{array}$ & $\begin{array}{l}\text {-Implement the use of } \\
\text { tourist packages for } \\
\text { potential tourists. } \\
\text {-Implement } \\
\text { promotions for } \\
\text { different times of the } \\
\text { year }\end{array}$ \\
\hline $\begin{array}{l}\text { (Defensive strategies) } \\
\text { Strengths vs threats }\end{array}$ & $\begin{array}{lr}\text { (Survival Strategies) } \\
\text { Weaknesses } \\
\text { Threats }\end{array}$ \\
\hline $\begin{array}{l}\text {-Implement the use of social } \\
\text { networks to publicize the } \\
\text { tourist attractions of the } \\
\text { region. }\end{array}$ & $\begin{array}{l}\text {-Create a training plan } \\
\text { for people who will } \\
\text { work in local } \\
\text { businesses. } \\
\text {-Create small local } \\
\text { short films and } \\
\text { distribute them } \\
\text { through the media. }\end{array}$ \\
\hline
\end{tabular}

Table 3 Maxi Mini / Maxi Maxi Matrix

Own Source

The detection of improvement opportunities for the provision of services and products are:

- Offer entrepreneurship workshops to the inhabitants of the region.

- Implement the use of tourist packages for potential tourists.

- Implement promotions for different times of the year.

- $\quad$ Offer to provide computer and marketing workshops to the people of the region to make use of new technologies.

- Implement the use of social networks to publicize the tourist attractions of the region.

- Create a training plan for people who will work in local businesses.

- Create small local short films and distribute them through the media.

\section{Results}

Improvement plan for the products and services offered in El Triunfo, B.C.S. The objective is to have a guide to enable the effective participation of the inhabitants in the development of the region. The plan includes: program, actions, resources, deadlines and performance indicators. See Table 4. 


\begin{tabular}{|c|c|c|c|c|}
\hline Program & Actions & Means & Term & $\begin{array}{c}\text { Indicator / } \\
\text { Performance }\end{array}$ \\
\hline $\begin{array}{l}\text { Workshops / } \\
\text { entrepreneur }\end{array}$ & \begin{tabular}{|l|} 
computing \\
English \\
Business \\
models \\
Business \\
Administration
\end{tabular} & $\begin{array}{l}\text { Instructor } \\
\text { Classroom } \\
\text { Office } \\
\text { supplies } \\
\text { Computer } \\
\text { Projector }\end{array}$ & $\begin{array}{l}6 \\
\text { months }\end{array}$ & $\begin{array}{l}100 \% \text { trained } \\
\text { entrepreneurs }\end{array}$ \\
\hline $\begin{array}{l}\text { Design / tour } \\
\text { packages }\end{array}$ & Computer & $\begin{array}{l}\text { Office } \\
\text { supplies } \\
\text { Computer }\end{array}$ & 1 month & Annual \\
\hline $\begin{array}{l}\text { Promotions } \\
\text { design }\end{array}$ & $\begin{array}{l}\text { Marketing } \\
\text { Design Expert }\end{array}$ & \begin{tabular}{|l} 
Office \\
supplies \\
Computer
\end{tabular} & 1 month & Annual \\
\hline $\begin{array}{l}\text { HR training } \\
\text { plan }\end{array}$ & \begin{tabular}{|l} 
Customer \\
Support \\
Organization \\
of spaces and \\
warehouse \\
Corporate \\
culture
\end{tabular} & $\begin{array}{l}\text { Instructor } \\
\text { Classroom } \\
\text { Office } \\
\text { supplies } \\
\text { Computer } \\
\text { Projector }\end{array}$ & $\begin{array}{l}6 \\
\text { months }\end{array}$ & $\begin{array}{l}100 \% \text { trained } \\
\text { human } \\
\text { resource }\end{array}$ \\
\hline $\begin{array}{lr}\text { Design } & \text { of } \\
\text { local } & \text { short } \\
\text { films } & \\
\end{array}$ & $\begin{array}{l}\text { Marketing } \\
\text { Design Expert }\end{array}$ & \begin{tabular}{|l} 
Computer \\
Camera
\end{tabular} & 1 month & $\begin{array}{l}\text { Designed } \\
\text { short film }\end{array}$ \\
\hline
\end{tabular}

Table 4 Improvement plan proposal Own Source

\section{Contribution}

In order to improve the quality of the products and services provided in the town of El Triunfo, this proposal for improvements to the services and products that is currently being generated has been designed, with which it is possible that the regional development, with the participation of the inhabitants of Triunfo BCS The improvements have been detected once the diagnosis was made directly in the field of action, including in it the assessment that has been determined by the users of the services and products that are prepared by the inhabitants of the region, and with the intention that through their participation and permanence as entrepreneurs, they will be managers of their own generation of self-employment. In the improvement proposal, the actions for their implementation are determined so that this facilitates the start-up directly with current and future entrepreneurs who can be integrated.

\section{Acknowledgments}

This project has been financed by the National Technologist of Mexico, to which we are infinitely grateful for the support that through the Technological Institute of La Paz to which we proudly belong, the objective has been the proposal to improve the products and services that are currently provided in Triunfo BCS. and through the Academic Body "Management of Organizational Processes" this project has been authorized.

\section{References}

Boisier, S. (Agosto de 2005). ¿Hay espacio para el desarrollo local en la globalizacion? CEPAL, 47-63.

Hernández, Z. T. (2014). Administración Estrategíca. México: Patria.

Llaurado, O. (12 de diciembre de 2014). Netques.com. Obtenido de https://www.netquest.com/blog/es/la-escala-delikert-que-es-y-como-utilizarla

Madoery, O. (2005). La primera generacion de politicas locales de desarrollo en Argentina: contexto, caracteristicas y desafios. Centro de Estudios de Desarrollo y Territorio. Universidad Nacional de San Martin.

OCDE. (2004). Evaluating local economic and employement development: How to assess what works among programmes and policies LEAD PROGRAME CODE. Paris, Francia: OCDEBanco Interamericano de Desarrollo.

Tesis.uson.mx/digital/tesis/docs/22230. (2011). Diagnostico y seguimineto a la emporesa Toynor. México: Digital. 